\title{
BOROBUDUR TEMPLE PRE AND POST COLONIAL ERA
}

\author{
Baskoro Suryo Banindro \\ Visual Communication Design Program \\ Faculty of Visual Art, ISI Yogyakarta \\ banindro@yahoo.com
}

\begin{abstract}
Borobudur temple is a heritage of Buddhism culture in Indonesia, which located at Magelang city, Central Java Province. The temple was built at the golden era of Syailendra dynasty, built among $800 \mathrm{AD}$ or around 9th century. Beside known as one of Indonesia's main tourism destination, it is also a central of Buddhism spiritual religion liturgies and rituals.

Borobudur ever was in a tremendous golden era but also the darkness was covered its existence until hundred of years and it's began to be revealed in the era of colonial. For decades, the rejuvenation and revitalization effort to rebuild the temple back to the original shape been accomplished. Through serious treatments, Borobudur becoming the inspiration source of cultural activities of various aspect that manifested, mainly history, arts, tourism, economy, research, science and also religion.

The walls of Borobudur are full of reliefs that picture the Buddhism philosophy, and turn out to be a masterpiece with a high aesthetic in the accession of civilization in its era. Now, beside stated as one of the World Heritages by UNESCO, also 2 titles given to the temple; as the archeology site heritages, the biggest Buddhism temple in the world, and also recorded in Guinness World Records.
\end{abstract}

Keywords: Borobudur, Colonial Era, Cultural Activity Inspirations.

Relevance to Visual Communication Design Practice: This study helps the visual communication design students to examine a deeper understanding of the history of art, especially the study of art objects associated with the existing iconography of the temple reliefs as the concept of creating a project idea book illustration, comics, infographics.

\section{Forestates}

Borobudur is a Buddhist temple and also one of the biggest Buddhist monuments in the world. In Tiong-Hoa Ethnic, this temple known as 婆羅浮屠 (Hanyu Pinyin: pó luó fú tú) in Mandarin language. There are many theories that trying to explain the name of this temple. One of them stated that this name maybe originated by the word "Sambharabhudhara" which means "mountains" (bhudhara) with terraces lays on its gradients (Casparis, 1981, 70 and 83).
As Historical residual, Borobudur nor only be the heritage for Indonesia, but also for the world. The restoration that realized since before and after colonial by involving many side, it is not yet perfectly brought it into the original manifestation, but the efforts at least, has saved Borobudur for the next 1000 years.

According to a theory that widely accepted, Borobudur built around the end of 8th century - the early of 9th century, and built in the age of Syailendra dynasty. The founder of Borobudur, King Samaratungga whom comes from Wangsa or dynasty of 
Syailendra is a king of Medang kingdom from Wangsa that empowered in the years of 792835 AD (Munoz, 2006, 171). For the architect that honored in designing this temple, as told by hereditary tales, is named Gunadharma. The possibilities of this temple built around the years of 824 ADand finished around the years of $900 \mathrm{AD}$ in the governance of Queen Pramudawardhani, the daughter of Samaratungga ${ }^{1}$.

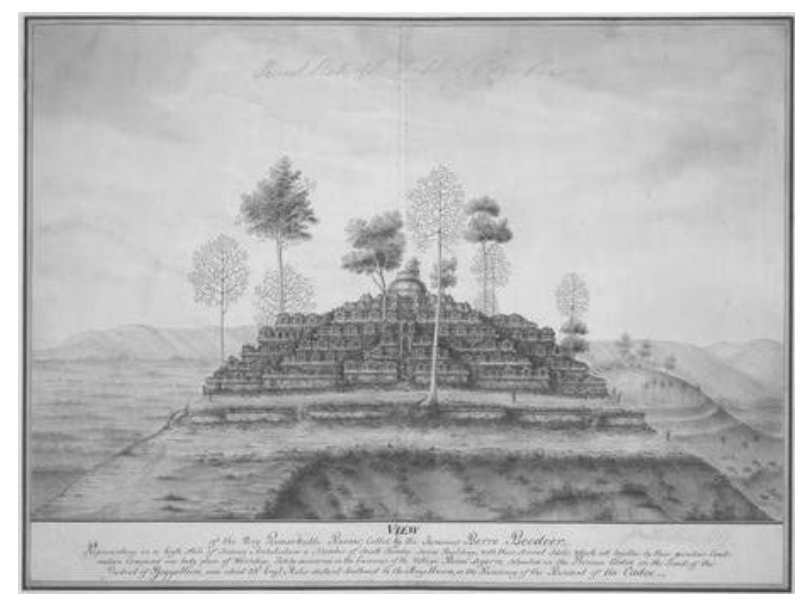

Figure 1 Borobudur temple drawing by P. Beedeer (Source: Wacana Nusantara)

Not only about the fact that this temple is located far up in the hills in rural of Java, But also the history of the temple's presence is still full of obscuring haze of mystery. The absence and the lack of epigraph or inscription that clearly stated about by whom and when the temple constructed adds the uproar sense to the drama of Borobudur existence. By the myths and folklores that written above, it is the Syailendra dynasty that in responsibility,

\footnotetext{
${ }^{1}$ Soekmono says that the inscription carved above the foot of the hidden temple reliefs have characteristics similar to writing graphics commonly used in royal inscriptions in the late 8 th century and early $9^{\text {th }}$ century, so it is clear that the temple of Borobudur likely founded around the year $800 \mathrm{AD}$
}

but the empirical truth about this news historically is remain unknown.

\section{Enlargement}

Few theories revealed by the experts about why Borobudur temple was abandoned and left unknown by Buddhist civilization in this area. One of the theories which proposed is Borobudur originally built around swamped habitat and then drowned by the eruption of Merapi volcano. That argument was taken from the Kalkutta inscription that written "Amawa" which means "Sea of Milk". That word then translated as lava of Merapi, the possibilities of Merapi buried by cold lava (mud-like materials) around the year of 800 $\mathrm{AD}$, along with the end of Mataram Empire in the year $930 \mathrm{AD}$ the next central civilization and culture of java moving to the east side in the year of $1006 \mathrm{AD}$. (Murwanto et.al., 2004, 459-463)

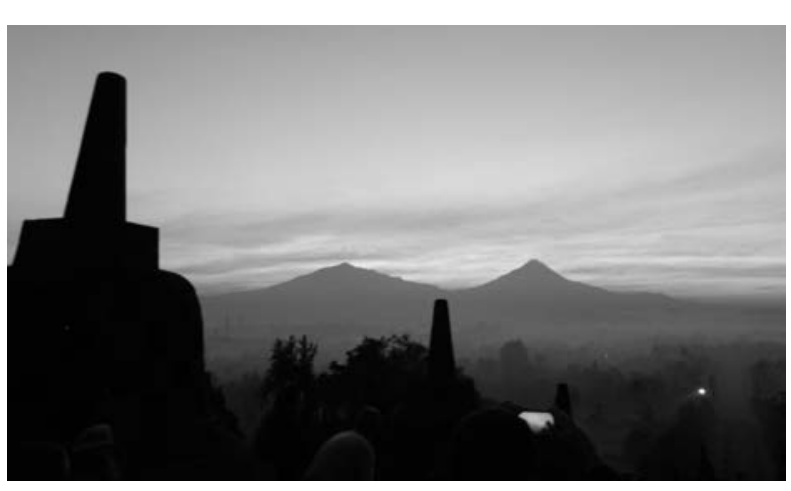

Figure 2 Borobudur was built not far from Mount merapi, the volcanic dust so that it becomes one of the causes of damage of the rock Temple. (Source: Baskoro SB, document)

Basic materials of Borobudur Temple are 2.000.000 pieces of stones, and for each one stone, it has hundred kilogram of weight. Amazingly, there is no cement used to agglutinate these stones. Stone by stone are 
just hooked up each other, which is up and bottom stone, left and right stone, and also front and back stone. If the temple projected from the sky, the result is Borobudur temple and its sculptures relatively symmetric. Borobudur construction formed a gradient leveling ground which has 10 floors. The temple sized $123 \times 123$ meters. The height is 42 meters before renovation and then 34,5 meters after renovation. It is because the lowest floors used as ground holder.

This Buddhist Temple has 1460 reliefs and 504 Buddhist stupas. Borobudur temple built used the Andesite rock material (Kartapranata, Kompas, Juni 1th, 2007), amount $55.000 \mathrm{M}^{3}$, the construction of the temple formed leveling pyramid with stairs in its four side (north, south east and west), there is no room in Borobudur where people just able to climb up and down only. On the real fundamental part, it is covered by 12.750 $\mathrm{M}^{3}$ Andesite stone as the breezeway of its level.

\section{The Origin Of The Name "Borobudur"}

There is no any written evidence which older that gave the name "Borobudur" to this temple. The only old document that directing the existence of this temple is the book of Nagara Kertagama, which written by $\mathrm{Mpu}$ Prapanca in the year of 1365 AD. It's written this book, that this temple used as place for meditation of Buddhism believer. Beside that, there are some other folks etimology, as example, the word of "Borobudur" originated from the phonetic sound of pronounce "para Buddha" (The Buddhist Believer) then audioly dragged turned to be "Borobudur".

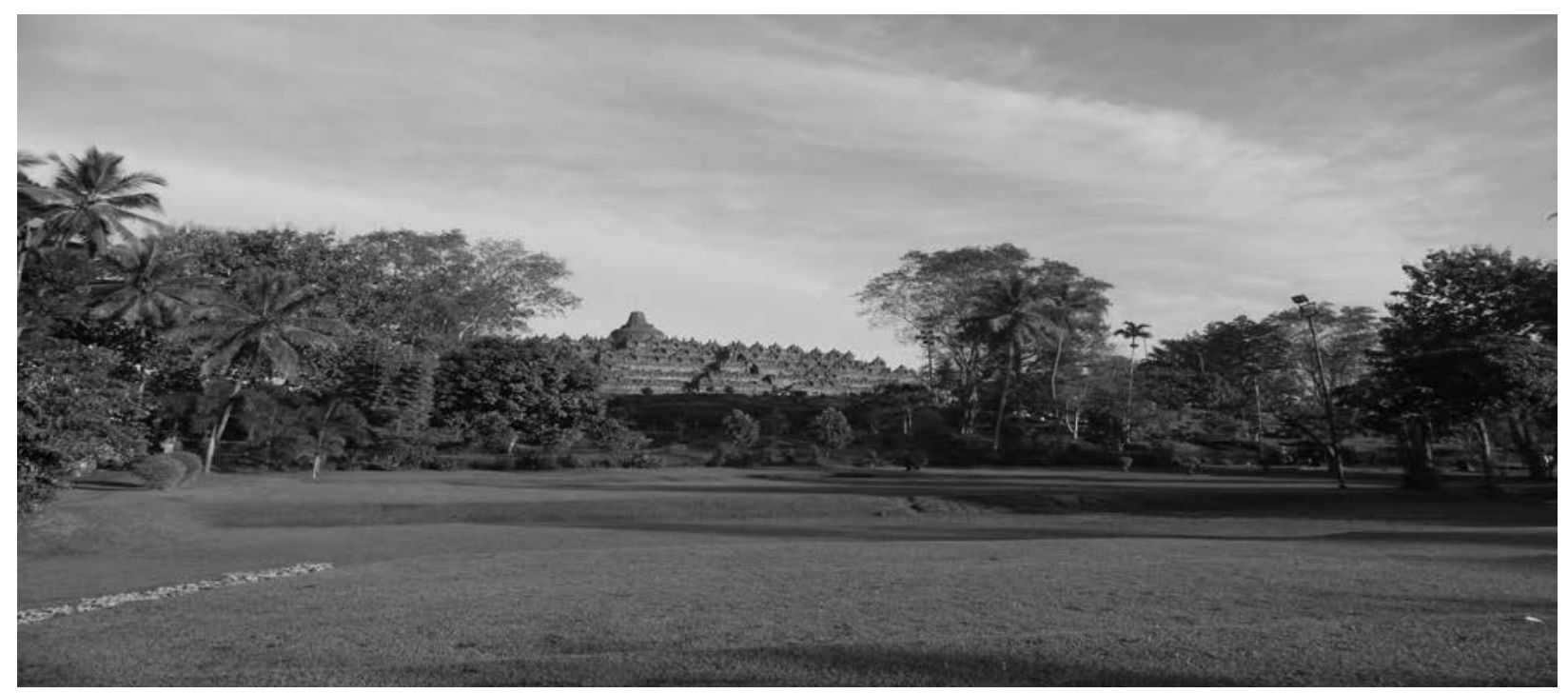

Figure 3 Borobudur means of "a vihara or dormitory in the hills", was build on hills in lake so likes Lotus flower in the bowl.

(Source: Baskoro SB, document) 
Other explanation is this name come from two words; "Bara" and "Beduhur". This word originally from the word "Vihara". There is also any another explanation which saying that "Bara" come from the Sankskrit language which means temple area and "Beduhur" means "High", or reminding that, in Balinese language it also means "up in the high". So, it could be means as "a vihara or dormitory in the hills". Beside that according to another source, it means "a terracering mountain (Budhara)", and also there is other source that stated it means "a vihara in high place". Borobudur is not only a manifestation of a temple but as a symbol of the Buddha Mahayana totality of life doctrine (Wagner, 1959, 104).

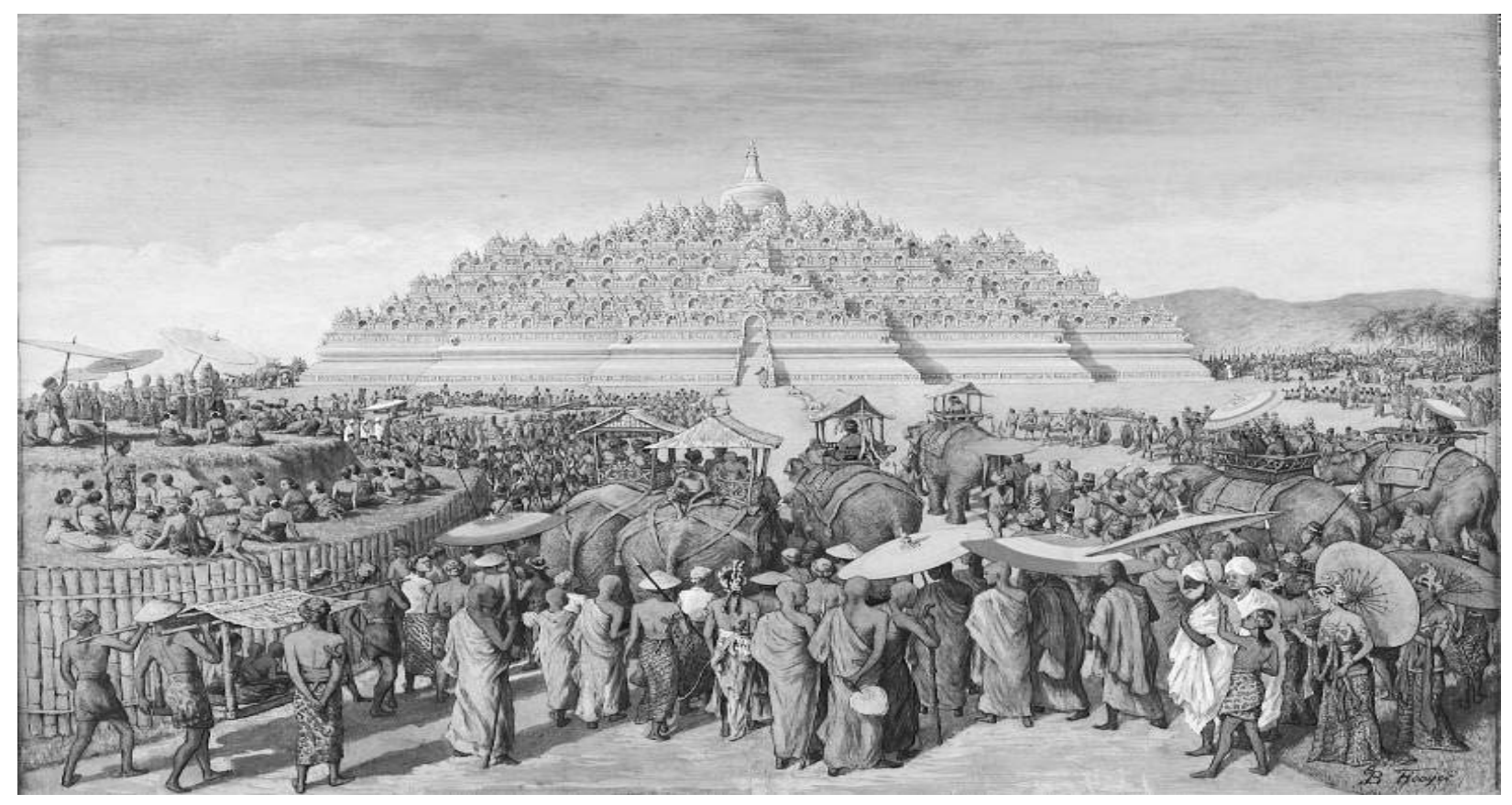

Figure 4 About only 150 years this temple used as the central of religion pilgrimage.

(Source: old lithography by G.B. Hooijer (1916-1919)

Borobudur, the temple that becoming the world's wonders, excrescence highest among the valleys and the lower grounds because of it's high. It is obvious that it was a truth the Borobudur temple was abandoned in a very long gap of time, even until few centuries this epic building face the ruining progress. About only 150 years this temple used as the central of religion pilgrimage, a very short time compared with its age when the workers working on its decoration or constructing the nature hill Borobudur
Temple with stones under the famous governance of Samaratungga, until the earlier of 19th century, the abandoned and forgotten Borobudur Temple successfully evacuated (Kempers, 1959, 45).

\section{Colonial Era}

The word "Borobudur" it self leads to the name that used by Sir Thomas Stamford Raffles, the General Governor of Great Britain in 1814, when English ruled the NetherlandsIndie (Hindia Belanda) in Java that rules until 
1816. When he heard a discovery of giantancient-kitchen-matters in Bumisegoro village near Magelang, so Raffles is the first person who care about this news, Raffles, after that commanding for digging the soil of Java to bring back another temples, which has a same path like Borobudur that buried by volcanic materials in the year of $1006 \mathrm{AD}$ (Bemmelen, 1970). Because of his big interest with Java's history, so Raffles immediately order H.C. Cornelius, a Netherlands engineer, to investigate the location of discovery at that time was as hills that covered by plants and bushes, start from that time, Borobudur temple pops out from the darkness of the past. Cornelius with the helps of 200 mens, cutting down the trees and eliminate the bushes that covered this mega-structure.

Because deciding about the old, fragile and about to crumble building, Cornelius reported to Raffles about this discovery with some pictures. By this discovery Raffles earned an honor as the first person who start the revitalization of Borobudur temple and earned the world's attention(Soekmono, 1991, 14). In 1835 , by the command of Hartman, Second Residence at that time, because his big interest in Borobudur temple, he command the entire citizen to clean all the area so the temple successfully dig and free from any view boundaries.

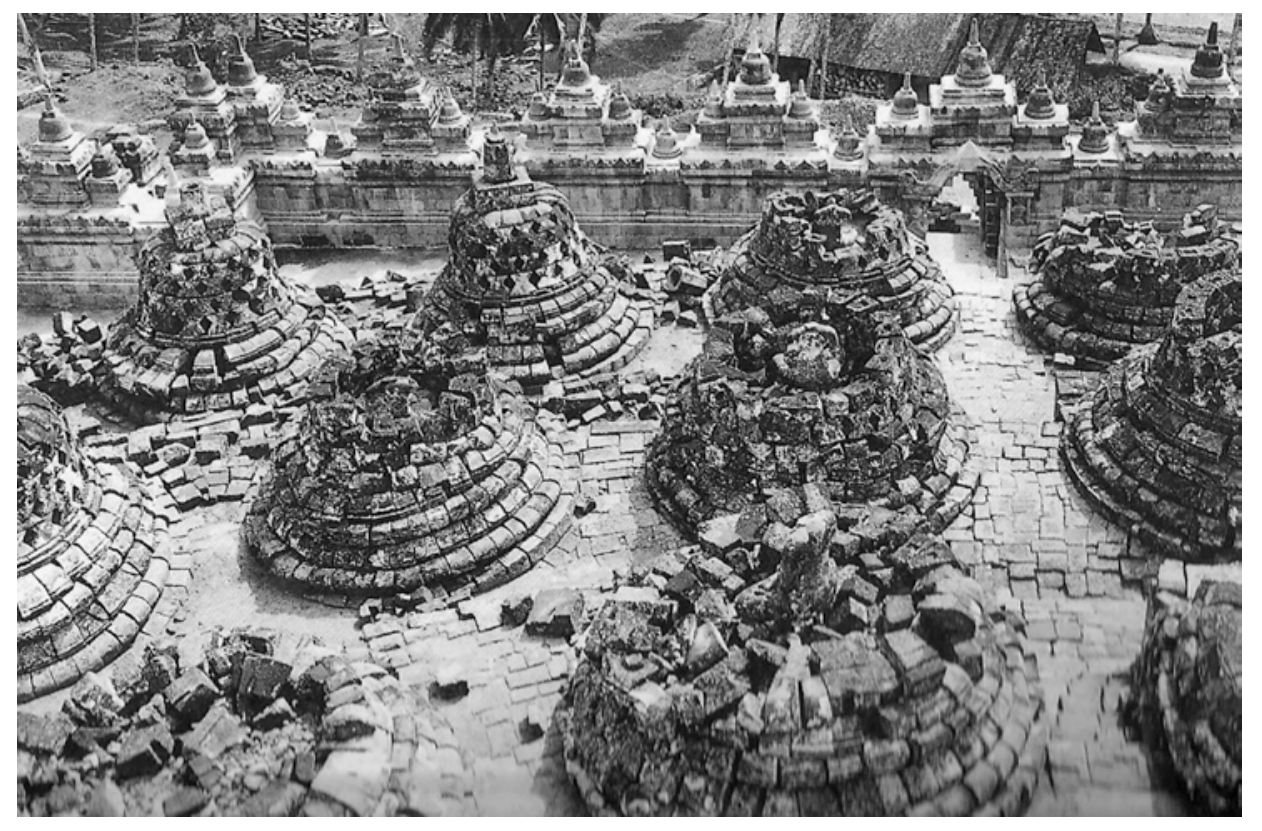

Figure 5 Borobudur temple when first time captured by Duthc historian Van Erp for to be rebuild. (Source: Troppen Museum)

After that, this temple continues to be recovered under the colonial of Netherland, and finally at the first sight, Borobudur is back to its old royal form. In 1930's, Niewenkamp ever deliver his science proposal for Borobudur Temple. Supported by geology research, Nieuwenkamp said that Borobudur Temple is not aimed to be as stupa/statuettes only, but also as a figure of lotus flower that floating in the lake. The lake that now was 
drained for such a long time; it was half of the field of Kedu, around the hills of Borobudur.

Historian J.G. de Casparis in his doctor degree dissertation in 1950 stated that Borobudur is a place for worship. According to the inscription of Karangtengah and Kahulunan, Casparis estimated that the founder of Borobudur is the King of Mataram, from Syailendra dynasty named Samaratungga, whom did the construction around 824 AD (Moertjipto et.al., 1993, 18). This Enormous building finally could be finished by the era of her daughter, Ratu Pramudawardhani. The construction of Borobudur (his) calculated earned half century of duration. Inside the inscription of Karangtengah also mentioned about a honorisation Land Sima (free taxes land) by Çrī Kahulunan (Pramudawardhani) to save the Kamūlān which called Bhūmi Sambhāra
(Soekmono, 1988, 46). This phrase "Kamūlān" originated from word that means "origin", "holy building" to respect the ancestors, probably the ancestor of Syailendra dynasty.

Casparis predicted that Bhūmi Sambhāra Bhudhāra in sanksksrit means "hills of group of goodness ten levels of boddhisattwa" is the real name of Borobudur. On the relief, Borobudur tell a story about a legend, with various in its story, there are the story of Wiracita Ramayana, reliefs of Jātaka story, and also Lalita Vistara. Beside that, there are also reliefs that picture the civilization condition at that time. For example, the reliefs about farmer's activities, that represents the development of farming technologies at that time and reliefs of ships, as representation of development of sailing at that time.

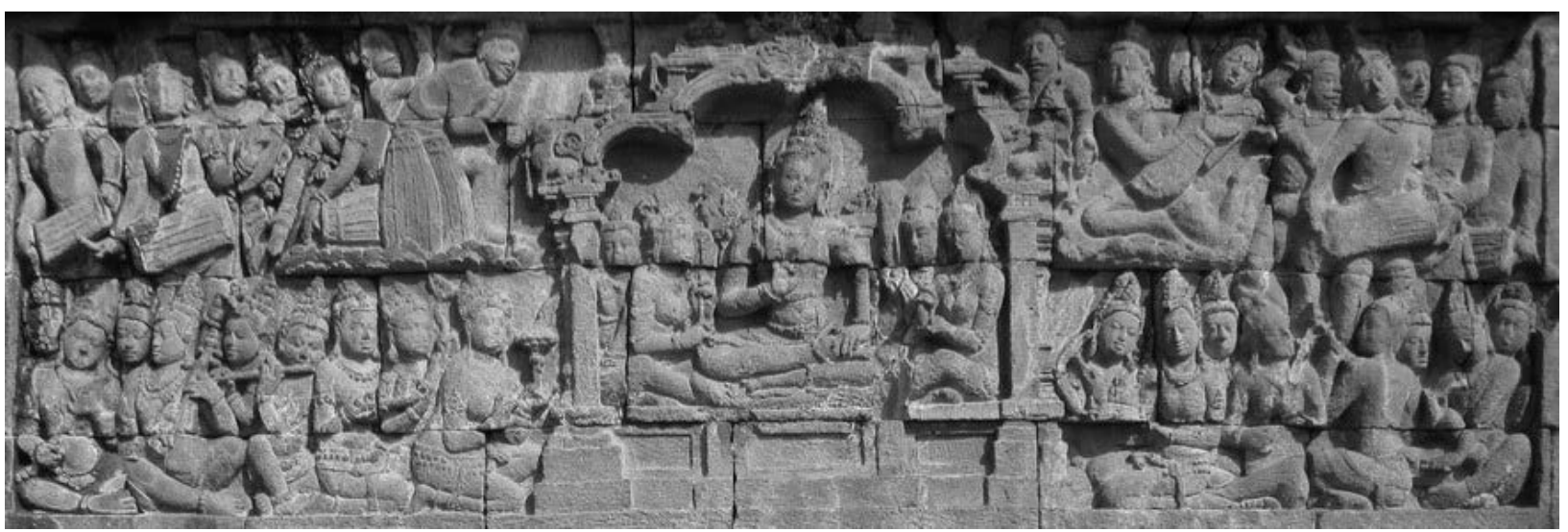

Figure 6 Bodhisattva in nirvana of Tusita scene of Lalitavistara, East Wall, first Panel (Source: Lalitavistara dalam relief Borobudur)

\section{Borobudur's Relief}

Reliefs that carved on the wall of the Temple parted as 4 main stories, which are Karmawibangga: stories about human's life at that age and the law of Karma, in 160 panels. Lalita Vistara: contained 120 panels and telling stories about the life of the Buddha Gautama from his birth, until his escape from the palace. Jataka \& Awardana: telling stories about Buddha as Prince Sidharta and few of his sacrifices in his reincarnation phase. And also Gandawyuda: 460 panels about Sudhana 
(a daughter of a rich merchant) whom looking for the one real genuine truth and also the oath of Sudhana to make Bodhisatva Samantabharda as his life role model.

The whole relief that existed in Borobudur represents the philosophy of the Buddha, every level symbolize the stage of human's life. Match with sect of Buddha Mahayana; every one who want to reach the highest stage as Buddha should through every step in these stages of life. Kamandhatu, The basic of Borobudur, represents the phase when human still tied with desire or lust. Rupadhatu, 4 steps above, represents human have been released from desire but still tied with form and shapes, at that stage, statues of Buddha coverless-ly open placed. Arupadhatu, 3 steps above, the statues of Buddha installed inside a stupa with holes, as a symbol when human releases from desires, form and shapes. Rupadhatu, the top, represents nirvana, the place where Buddha's lives.

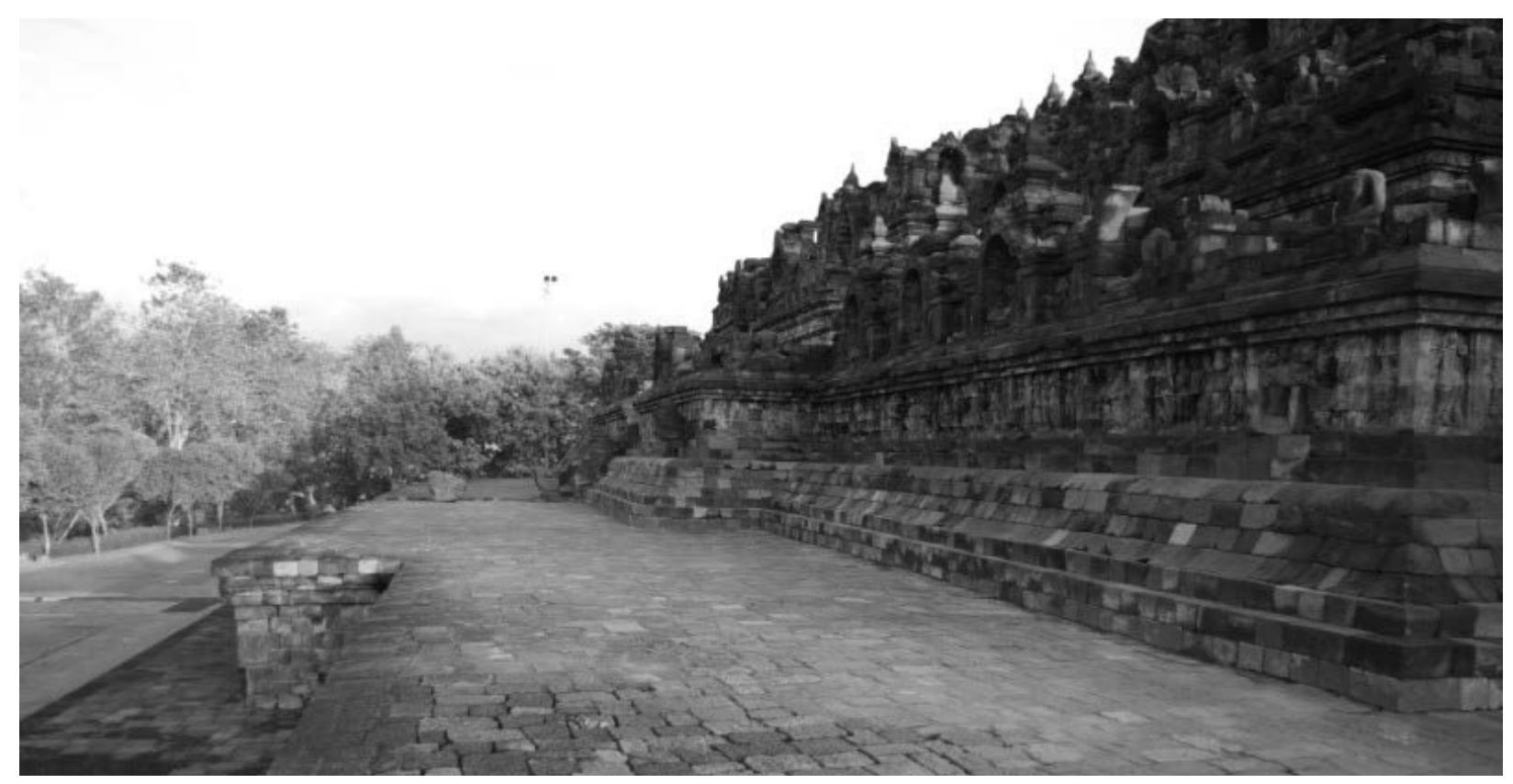

Figure 7 Kamadhatu stage, one of the foot of the temple that contains pictures of human life.

(Source: fannyndep.blogspot.com)

On the wall of every stage, except for the terraces of Arupadathu, there are bas-relief panels which carved so detailed and smooth (Cockrem, May 18, 2008, The Buddhist Channel.tv). Reliefs and decorative pattern Borobudur has naturalist style with ideal proportion and a very good and smooth aesthetic taste. These Reliefs are so beautiful, it's even stated as the most elegant in the art of Buddhism world. Borobudur reliefs shows us many pictures; like a figure of kind humans, aristocrat, peasants, or ascetics, various kind of plant and animal, also shows us the picture of Nusantara's traditional vernacular building. Borobudur is not far from a holy book which recording every aspect of life of the ancient Java civilization. Many archeologist researching about the ancient life in ancient Java and Nusantara in the $8 \& 9$ Century by paying attention and 
studying the reliefs of Borobudur. Stage house, paddy rice granary, palace, and temples, jewelries, costume also weaponry, various plants and animal, transportation devices, and of the most famous relief is The Ship of Borobudur ("The Cinnamon Route", Borobudur Park. html).

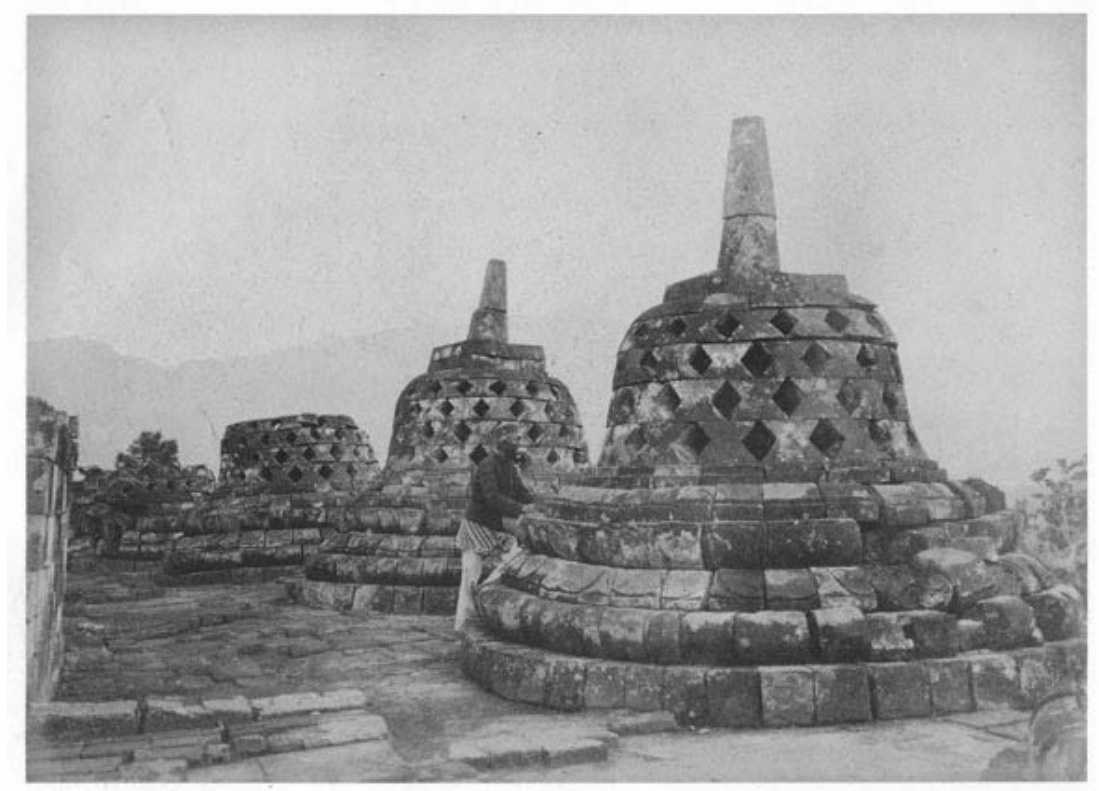

Figure 8 Kassian Cepas is the real in-lander in colonialism, was a portrait artist whom succeed to documented Borobudur when in broken condition and also after the revitalization.

(Source: KITLV)

Colonial influential person that succeed to documented the Borobudur are; the collection of painting of building and reliefs of the temple done by Wilsen for 4 years long. Since 1849 and Brumund 1856, and for the photo documentary, taken by Van Kinsbergen in 1873 (Soekmono, 17). Kassian Cepas is the real in-lander in colonialism, was a portrait artist whom succeed to documented Borobudur when in broken condition and also after the revitalization of the temple. (http://www.geheugenvannederland.nl).

In this colonial era, in 1896, few of Buddha statue with 30 stones with relief, 2 statue of lion, and few statue of Kala, stairs and gate sent to King of Thailand,
Chulalongkorn, who visits Netherlands Indie (now Indonesia) as prize from the government at that time.

\section{Pasca-Colonial}

After Indonesia's independency, in 1956, Indonesia's government asks for help from UNESCO to study about the damage of Borobudur. Then in 1963, the government officially releases a policy to start the revitalization of Borobudur Temple with helps from UNESCO. But this action actually begins at 10 August 1973 and the revitalization progress done in 1984. Since 1991, Borobudur temple was proposed as The World Heritage Site from UNESCO. As a 
masterpiece, Borobudur has been inspiring the modern practical life, not only as a discourse, but also its name turns out to be a frame of visual diversities, Borobudur name now used as a name of various object like as a name of university, hotel, art works; painting, batik fiber, statues, graphic design, opera, and also interestingly, Borobudur this lately seen as a giant comic in the 2 dimensional form that horizontally has 5 Kilometers long and many more.

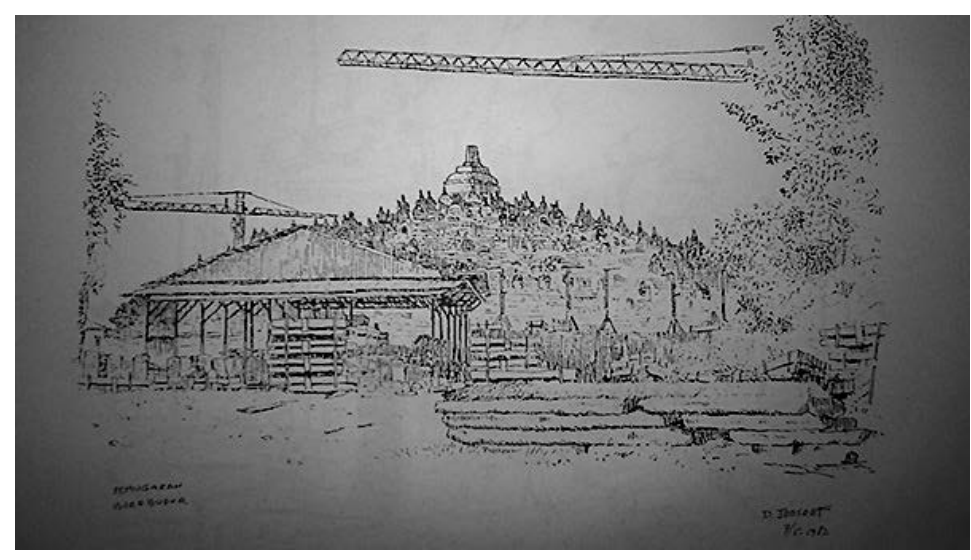

Figure 9 Borobudur under construction, drawing by Daoed Joesoef, Minister of education and culture (Source: Borobudur book, 1973)

As a product of cultural heritage, Borobudur apparently still keeping so much mystery that unsolved until now, but, the evidence of its presence in this little city of Magelang, Central Java, proved that in the past, the civilization of Netherlands Indie have faces the climax of its cultural development and the golden age in Religious, architectural, technology, and high level of visual arts is undeniable.

\section{Closing}

After the renovation is over, by UNESCO now Borobudur listed as World Heritage Site by the year of 1991. This fact written under the cultural criteria; first, to represent a humane creative genius masterpiece, second, to shows the importance of the exchange in the values of humanity, in the horizon of time or in the area of world culture, in development of architecture or technology, monumental art, city master plan, or landscape design, and fourth, to directly or concretely involved with the phenomenon or an alive tradition, with ideas, or with faith, with artistic works, and the significant universal literature that passing on.

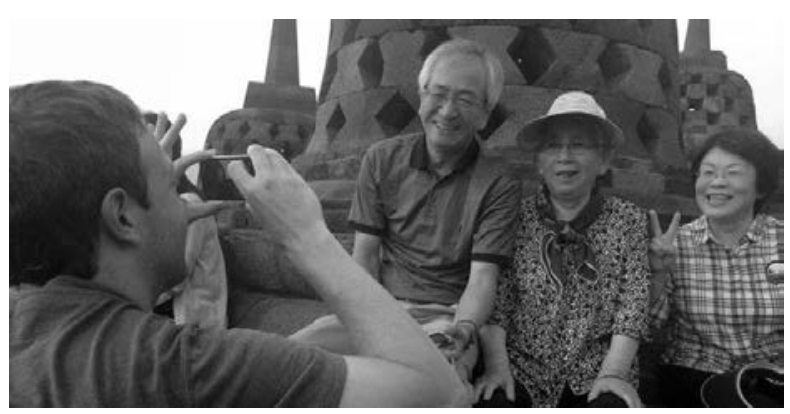

Figure 10 Mark Zuckerberg So Artisan Impromptu Photos at Borobudur (Source: tekno.kompas.com) 
Now, Borobudur reborn as a place that worshipped by the people of the world. The visitors of Borobudur are not only the local tourist, but also the domestic tourist who came from another part of the world. Start from the general people, politician, artist, important national figure, the cultural researcher, serve a time for them selves to visit and stay to enjoy its beauty. And also not forgotten, exactly, the believer of Buddhism also always held rituals of their religion in Borobudur. If we see from the distance, Borobudur would see as a leveling terraces construction, like pyramid, and a stupa. It's totally different with the giant pyramid of Egypt and the pyramid of Teotihuacan in Mexico. Borobudur temple is another version of pyramid building. Borobudur pyramid wouldn't ever be discovered in other part of the world, in every country, even in India. That is one of the endless number of Borobudur great specification which also signature the Buddhism architecture in Indonesia.

\section{BIBLIOGRAPHY}

[1] Casparis, G. de. (1981). "The Dual Nature of Barabudur", in Gómez and Woodward.

[2] Bemmelen, Van, R.W. (1970). The Geology of Indonesia (Second Edition). The Hague: Martinus Nijhoff.

[3] Kempers, A.J., Bernet. (1959). Ancient Indonesian Art. MA: Harvard University Press.

[4] Mertjipto dan Bambang Prasetyo. (1993). Borobudur, Pawaon dan Mendut, Yogyakarta: Kanisius.

[5] Michel Munoz, Paul. (2006). Early Kingdoms of the Indonesian Archipelago and the Malay Peninsula. Singapore: Editions Didier Millet.
[6] Soekmono, R. (1991). Satu Abad Usaha Penyelamatan Candi Borobudur, Yogyakarta: Kanisius.

[7] Soekmono, R. (1988). Pengantar Sejarah Kebudayaan Indonesia 2, Yogyakarta: Kanisius.

[8] Wagner, Frits A. (1959). Indonesia the art of Island Group. NY: Crown Publisher, Inc.

\section{Special report:}

Murwanto, H., Y. Gunnell, S. Suharsono, S. Sutikno, and F. Lavigne, "Borobudur monument (Java, Indonesia) stood by a natural lake: chronostratigraphic evidence and historical implications", No. 14, 3 edition, 2004.

Voûte, Caesar and Mark Long. Borobudur: Pyramid of the Cosmic Buddha. D.K. Printworld Ltd

Tom Cockrem, Sydney Morning Herald, May 18,2008 , "Temple of enlightenment", The Buddhist Channel.tv.

"The Cinnamon Route", Borobudur Park

http://www.geheugenvannederland.nl/?/en/co llecties/pioniersfotografie_uit_nederlands -indie/kassian_cephas

kebudayaanindonesia.net/kebudayaan/843/ca ndi-borobudur

"Largest Buddhist temple". Guinness World Records. Guinness World Records.

Kartapranata, Gunawan, Infografik: "Upacara Waisak di Borobudur", "Kompas" daily, Juni 1th, 2007 